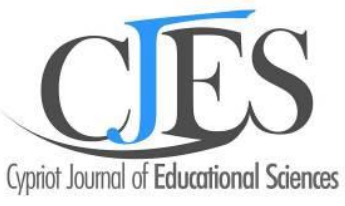

www.cjes.eu

\title{
Some personal and professional variables as identifiers of teachers' lifelong learning tendencies and professional burnout
}

Hatice Yildiz-Durak*, Faculty of Science, Department of Computer Technology and Information Systems, Bartin University, 74100 Bartin, Turkey https://orcid.org/0000-0002-5689-1805

Suleyman Sadi Seferoglu, Faculty of Education, Department of Computer Education and Instructional Technology, Hacettepe University, 06800 Ankara, Turkey https://orcid.org/0000-0002-5010-484X

Nihal Sen, Faculty of Education, Lifelong Learning and Adult Education, Bartin University, 74100 Bartin, Turkey https://orcid.org/0000-0002-8374-144X

\section{Suggested Citation:}

Yildiz-Durak, H., Seferoglu, S. S. \& Sen, N. (2020). Some personal and professional variables as identifiers of teachers' lifelong learning tendencies and professional burnout. Cypriot Journal of Educational Science. 15(2), 259-270. https://doi.org/10.18844/cjes.v15i2.3797

Received August 5, 2019; revised February 12, 2020; accepted April 1, 2020.

${ }^{\circ} 2020$ United World Center of Research Innovation and Publication. All rights reserved.

\begin{abstract}
In this study, it is aimed to determine teachers' lifelong learning (LLL) tendencies. It is also aimed to reveal the variables that are associated to the LLL tendencies and to predict its levels. This research, which was a relational model, was utilised in spring term of 2017-2018 academic year. The participants of the study consisted of 199 teachers working at various school levels associated with the Ministry of National Education. According to the results of the study, it was found that demographic, occupational variables and the burnout in the multiple linear regression analysis were significant predictors of LLL tendency. When the variables are considered one by one, it is concluded that the predictors of teachers' LLL tendencies are age, occupational seniority and burnout.
\end{abstract}

Keywords: Teachers, lifelong learning tendency, personal variables, occupational variables, occupational burnout. 


\section{Introduction}

Nowadays, the continuous development of information technologies influences what type of competencies information society individuals need to pose in using those technologies effectively. Because of the rapid changes observed in communal living, individuals have to acquire new knowledge and skills. At this point, it can be stated that lifelong learning (LLL) has gained more importance. The concept of LLL points out the importance of improving the knowledge, skills and competences of individuals in order to be successful and happy members of knowledge society from birth to death (European Commission, 2002). LLL also aims to provide knowledge and skills to the community, and ultimately, opportunities to raise the level of welfare (Chapman et al., 2003).

LLL refers to a period that requires an individual to develop own competences and skills within his/her lifetime (Demirel, 2009). LLL, which includes formal and informal education, involves the ability of individuals to develop their qualifications, understanding and abilities to solve the problem, and to be able to transfer these to other situations (Sonmez, 2007).

There are many components (e.g., politics, cultural structure, economy, etc.) of LLL. However, in order for LLL to take place, first of all, restrictions, such as place, time and socio-economic level (differences due to the digital divide) should be removed (Gunuc, Odabasi \& Kuzu, 2012). In this context, the use of technology, which is one of the components of LLL, is considered to be very important for the sustainability of LLL. Components of LLL are presented in Figure 1.

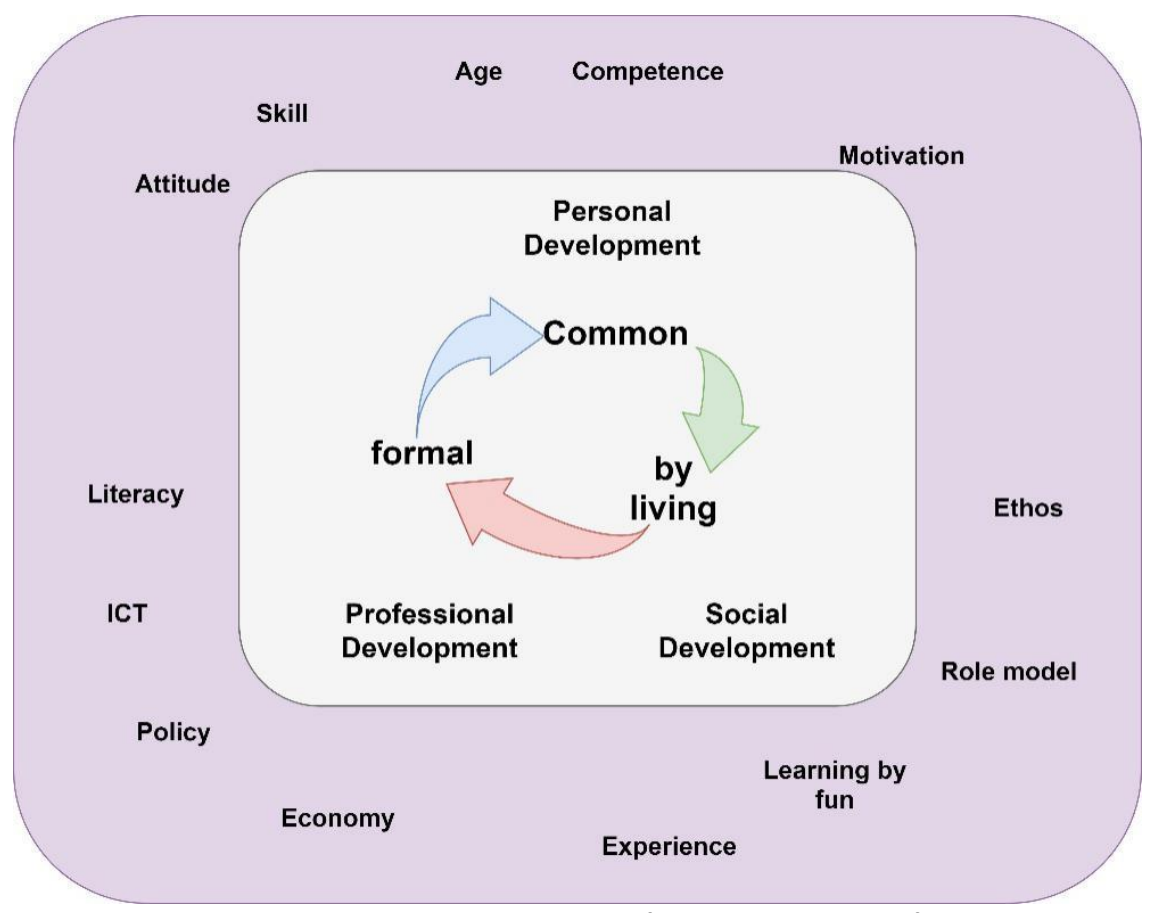

Figure 1. Components of LLL (Gunuc et al., 2012)

These days, in which rapid change and development take place in every field, the concept of LLL is examined by many researchers and institutions. The need for LLL is getting more and more important every day. As a matter of fact, in order to be able to adapt to these changes and developments and to have a problem-free integration process; the existing knowledge, skills, competencies and abilities of the individuals should be developed (Kilic, 2015).

Today, LLL is a phenomenon that affects and directs educational policies (Diker-Coskun, 2009). In order to examine and evaluate this phenomenon in every aspect, it is necessary to define it conceptually and to identify the related situation and variables. LLL is influenced by social, 
psychological, cultural and personal situations (Damy, 2020; Darkenwald \& Merriam, 1982; Gorard \& Selwyn, 2005; Gorard, Selwyn \& Madden, 2002; Maxted, 1999). Therefore, it could be claimed that more studies that address LLL situations of participants with different profiles are needed. This is because LLL is about providing people with a possibility to update their basic skills and bringing learning opportunities to a higher level in line with the principle of equality (European Commission, 2019).

With the importance of the concept of LLL, the interest towards this subject in the literature has increased. When the studies on LLL is investigated, it is noticed that teachers, teacher candidates, bachelor's level students and high school students are selected as study groups (Brahmi, 2007; Coskun \& Demirel, 2012; Demiralay \& Karadeniz, 2008; Evin Gencel, 2013; Izci \& Koc, 2012; Kara \& Kurum 2007; Karakus, 2013; Koksal \& Cogmen, 2013; Loads, 2007; Oral \& Yazar, 2015; Sahin \& Durak, 2018; Saritepeci \& Orak, 2019; Tunca, Sahin \& Aydin, 2015; Uzunboylu \& Hursen, 2011; Vanichvatana, 2020; Yildiz-Durak \& Saritepeci, 2019). When these studies are examined, it is noteworthy to mention that almost all of them have emphasised that teachers have a decisive and critical role in LLL. However, it is also noticed that LLL was addressed in terms of policies in some studies in the literature (Akbas \& Ozdemir, 2002; Beycioglu \& Konan, 2008; Budak, 2009; Cansever, 2009; Gunuc et al., 2012; Tamer, 2014). In addition, teachers' motivation to learn has also been emphasised in these studies. In this context, it could be claimed that in order for teachers to be effective teachers, they must acquire LLL skills and also they should have positive perceptions about LLL.

Occupational burnout is one of the most important factors affecting perceptions of teachers towards LLL. Occupational burnout can be described as a mental syndrome that occurs as a result of experiences involving various stress factors in the occupational settings. These experiences include feeling tiredness, depersonalisation and personal failure of individuals (Maslach \& Goldberg, 1998). When the studies on burnout were examined, it was seen that the precursors of burnout are excessive workload, ambiguous job description and function complexity, occupational setting and institutional or situational features resulting from vocational features and personality traits (Maslach, Schaufeli \& Leiter, 2001). Moreover, the results of burnout can be evaluated in individual and organisational contexts (Durak \& Saritepeci, 2019). According to Maslach et al. (2001), the individual and organisational consequences of burnout result as low level of productivity in work environments. As a result of burnout, teachers lose their ideals of professions, become unwilling and they are alienated from their profession (Troman \& Woods, 2000). This situation inevitably will affect teachers' LLL tendency. Since there is no study on burnout and LLL perceptions among published studies, it is thought that this research could be an important contribution to the literature.

\subsection{Why teachers?}

The main objective of LLL is to equally and flexibly support access to learning opportunities and learning experiences in all the age groups (Akkoyunlu, 2008). Teachers have the most important role in the realisation of this purpose (Kazu \& Erten, 2016). Therefore, it is thought that teachers, with their LLL competencies and attitudes towards LLL, will be role models for students in LLL applications where learning to learn is the key point (Yaman \& Yazar, 2015).

On the other hand, one of the important skills that should be gained in the vocational education of teachers within the theme of LLL is to improve the attitude towards LLL positively (Erdamar, Demirkan, Saracoglu \& Alpan, 2017). Teachers' positive attitude towards LLL will affect their students in a positive way. In addition, it can be stated that individuals who have positive attitude towards learning will have high motivation and eagerness to learn throughout their life. Therefore, it is assumed that the individuals' perceptions about LLL in the information society depend on teachers' perceptions about LLL. In this direction, it is thought that studying teachers' attitude about LLL would be effective in the success of LLL applications. Furthermore, knowing teachers' perceptions of LLL will also be useful in developing relevant programs. 


\subsection{Aim of the study}

In this research, it is aimed to determine the LLL tendencies of teachers. It also aimed to reveal the variables that are associated to the tendencies of LLL and that predict the tendency levels. In order to achieve the stated aim, research questions are developed as follows:

- How are teachers' LLL tendencies?

- How are the burnout levels of teachers?

- What is the relationship between teachers' personal, professional variables, occupational burnout levels and LLL tendencies?

- Do personal, professional variables and occupational burnout levels significantly predict teachers' LLL tendencies?

\section{Method}

The model of this study is a relational model because it examines the relationship between teachers' personal, professional variables, levels of occupational burnout and LLL tendencies.

\subsection{Study group}

This study was carried out in spring semester of 2017-2018 academic years. The participants of the study consisted of 199 teachers working at various school levels, including primary, secondary and high schools. The research group consisted of the teachers who participated in the study on a voluntary base. The participant teachers are working in the schools where the researchers could reach by using convenience sampling method. $29.7 \%$ of the teachers participated in the study were male and $70.3 \%$ were female. $45.2 \%$ of the participants are between the ages of 31 and 40 . The majority of the participants (40.2\%) have 1-5 years professional teaching experience. An almost similar distribution is observed in terms of branch as well.

\subsection{Data collection tools}

In this research, a total of three data collection tools were used to collect the data.

\subsubsection{Personal information form}

The Personal Information Form was developed to collect data related to demographic and occupational status (age, gender, years of job experience, educational status, branch, type of school, socio-economic status of the school environment, number of students in the district/city and in the school, etc.) of the study group. This form, which was developed by the researchers, consists of 10 items in total.

\subsubsection{Maslach burnout inventory}

This scale was originally developed by Maslach and Jackson (1981) to evaluate burnout and was adapted to Turkish by Ergin (1992). This scale is a measurement tool developed especially for occupational fields which require face-to-face relations and aim to provide direct services to people. This tool consists of 22 items and 3 sub-dimensions. Participants were asked to respond to items of the scale by scoring with ' $1, \ldots 5$ '. The calculated Cronbach's alpha coefficient is 0.87 for the scale and $0.92,0.84,0.79$ for the sub-dimensions respectively.

\subsubsection{Teachers' LLL tendencies scale}

This scale was developed by Diker-Coskun and Demirel (2010). The scale is composed of 27 items and 4 sub-dimensions. The items in this 6-point Likert scale are scored in the range of '1-totally does not fit ... 6-totally fits'. Cronbach's alpha coefficient is 0.80 for the whole scale and $87,0.80,0.78,0.86$, for the sub-dimensions, respectively. 


\subsection{Data collection}

The data collection tools used in the study were applied to the participants through an online survey. The survey was presented with guidelines prepared for the potential participants. Participants took part in the study on a voluntary basis. During the application process, it has been tried to reach teachers from all branches in order to include a wide range of participant teachers.

\subsection{Analysis of data}

In the study, descriptive analyses and parametric tests, which are expressed as 'correlation and regression analysis', were used to analyse the data. Multiple linear regression analysis (MLRA) was preferred for data analysis. Before the analysis, the dependent variable of the study (LLL tendencies of teachers) and independent variables (personal variables, professional variables and burnout) were evaluated according to the assumptions of MLRA.

\section{Findings}

The findings are presented in a way to answer the research questions determined in line with the aim of this research.

\subsection{Teachers' LLL tendencies and burnout levels}

The first two research questions of this study were defined as 'How are teachers' LLL tendencies?' and 'How are the burnout levels of teachers?' In order to find answers to these question; arithmetic mean, standard deviation values were calculated to determine teachers' LLL tendencies and burnout levels. The data related to these calculations are presented in Table 1.

Table 1. Distribution of data on teachers' LLL tendencies and burnout levels.

\begin{tabular}{lcccccc}
\hline & $\boldsymbol{k}$ & Min. & Max. & Mean & Mean $/ \boldsymbol{k}$ & SD \\
\hline Teachers' LLL tendencies & 27 & 96.00 & 162.00 & 139.98 & 5.18 & 15.38 \\
Motivation & 6 & 24.00 & 36.00 & 33.09 & 5.52 & 2.85 \\
Persistence & 6 & 24.00 & 36.00 & 31.25 & 5.21 & 3.36 \\
Deprivation in arranging & 6 & 10.00 & 36.00 & 30.62 & 5.10 & 5.54 \\
learning & 9 & 22.00 & 54.00 & 45.02 & 5.00 & 7.98 \\
Deprivation of curiosity & 22 & 31.00 & 100.00 & 57.80 & 2.63 & 10.23 \\
Burnout of teachers & 9 & 14.00 & 45.00 & 26.44 & 2.94 & 4.93 \\
Emotional exhaustion & 5 & 7.00 & 25.00 & 14.44 & 2.89 & 3.60 \\
Depersonalisation & 8 & 9.00 & 30.00 & 16.92 & 2.12 & 4.28 \\
Personal success & & & & & &
\end{tabular}

$k=$ Number of items.

According to the data presented in Table 1, the total mean score of the teachers who joined in this research on the LLL scale was highest for the 'Motivation' sub-scale $(\bar{X}=33.09, \mathrm{SD}=2.85)$. Moreover, the lowest mean was for 'deprivation of curiosity' sub-scale $(\bar{X}=45.02, \mathrm{SD}=7.98)$. The total score obtained from the scale was 139.98. The upper limit of moderate level of the scale for evaluating the LLL tendency scale was determined as 94.5 by Diker-Coskun and Demirel (2010). Thus, the scores of the teachers on the scale of LLL tendencies can be considered high. In the total mean score taken from the occupational burnout, the highest score was observed in the 'emotional exhaustion' $(\bar{X}=26.44$, $\mathrm{SD}=4.93)$ sub-scale. In addition, the 'Personal success' sub-scale had the lowest mean $(\bar{X}=16.92$, $\mathrm{SD}=4.28)$ score. 


\subsection{The relationship between teachers' LLL tendencies and various variables}

The third research question of this study was formed as 'What is the relationship between teachers' personal, professional variables, occupational burnout levels and LLL tendencies?' In order to find an answer to this question, Pearson-Correlation coefficients were calculated to examine the relationship between level of teachers' LLL and various variables. The results of the analysis are presented in Table 2.

Table 2. Distribution of correlation coefficients that shows the relationship between personal, occupational variables of teachers and their burnout levels, and LLL tendencies

\begin{tabular}{|c|c|c|c|c|c|c|c|c|c|c|}
\hline Variables & 1 & 2 & 3 & 4 & 5 & 6 & 7 & 8 & 9 & 10 \\
\hline 1. LLL tendency & 1.00 & & & & & & & & & \\
\hline 2. Gender & -0.025 & 1.00 & & & & & & & & \\
\hline 3. Age & $-0.221^{*}$ & -0.118 & 1.00 & & & & & & & \\
\hline $\begin{array}{l}\text { 4. Years of job } \\
\text { experience }\end{array}$ & $-0.399 * *$ & -0.068 & $0.760 * *$ & 1.00 & & & & & & \\
\hline 5. Educational status & 0.141 & 0.073 & -0.056 & 0.039 & 1.00 & & & & & \\
\hline 6. School type & -0.014 & -0.076 & 0.033 & -0.066 & -0.038 & 1.00 & & & & \\
\hline $\begin{array}{l}\text { 7. Socio-economic } \\
\text { status of the school } \\
\text { environment }\end{array}$ & 0.033 & -0.153 & 0.019 & 0.033 & 0.064 & 0.129 & 1.00 & & & \\
\hline $\begin{array}{l}\text { 8. Total number of } \\
\text { students that are } \\
\text { being taught }\end{array}$ & $-0.262^{*}$ & -0.125 & 0.148 & $0.188^{*}$ & 0.110 & $0.167 *$ & $0.343 * *$ & 1.00 & & \\
\hline 9. Weekly course load & $-0.228^{*}$ & 0.030 & -0.008 & -0.016 & $-0.291 * *$ & 0.013 & $0.263^{* *}$ & $0.183^{* *}$ & 1.00 & \\
\hline 10. Burnout & $-0.382 * *$ & $-0.171^{*}$ & 0.137 & 0.131 & 0.052 & 0.045 & 0.155 & 0.022 & 0.098 & 1.00 \\
\hline
\end{tabular}

According to the data presented in Table 2, the correlation coefficients between variables vary between -0.008 and 0.760 . The independent variable, LLL tendency, has the highest correlation with the 'years of job experience' variable $(r=0.399 p<0.01)$ and has the lowest correlation with the 'type of school' variable $(r=-0.014 ; p<.05)$.

\subsection{Predictive status of teachers' personal, professional variables and burnout levels on teachers' LLL tendencies}

The fourth research question of this study was defined as 'Do personal, professional variables and occupational burnout levels significantly predict teachers' LLL tendencies?' A MLRA was performed to answer this question. While regression analysis was performed, the variables were included in the model at the same time. The results of the MLRA performed in this context are presented in Table 3.

Table 3. Distribution of MLRA results on the predictiveness of the levels of personal, occupational variables of teachers and their burnout levels with regard to LLL tendencies

\begin{tabular}{lcccc}
\hline \multicolumn{1}{c}{ Variables } & $\boldsymbol{B}$ & $\boldsymbol{B}$ & $\boldsymbol{t}$ & $\boldsymbol{p}$ \\
\hline Gender & $-1,115$ & -0.033 & -0.318 & 0.751 \\
Age & -0.463 & -0.304 & $-1,975$ & 0.047 \\
Years of job experience & -0.675 & -0.312 & $-1,991$ & 0.044 \\
Educational status & $-6,923$ & -0.136 & $-1,220$ & 0.226 \\
School type & $-2,331$ & -0.066 & -0.625 & 0.533 \\
Socio-economic status of the school environment & 0.945 & 0.039 & 0.337 & 0.737 \\
\hline
\end{tabular}




$\begin{array}{lcccc}\text { Total number of students that are being taught } & 0.004 & 0.105 & 0.923 & 0.358 \\ \text { Weekly course load } & -0.072 & -0.032 & -0.280 & 0.780 \\ \text { Burnout } & -0.551 & -0.300 & -1,946 & 0.049\end{array}$

$R=0.488, R^{2}=0.238$

$F(9,189)=2.731, p=0.000$

The data presented in Table 3 indicates that the model is statistically significant $(p<0.001)$. In addition, it was found that the demographic variables, professional variables and burnout explained $23 \%\left(R^{2}=0.238\right)$ of the total variance on LLL tendency. According to standardised MLRA coefficients, when the predictive variables were examined, it was found that seniority was the most important (strong) predictor of LLL tendency. Here, it is important to note that the correlation is in negative direction. Therefore, LLL tendency decreases as years of job experience increases. In terms of importance, this variable is followed by age, burnout, education status, total number of students that are being taught, type of school, socio-economic status of the school environment, gender and weekly course load, respectively. When the $t$-test results are examined, it is seen that age, years of job experience and burnout variables are important (meaningful) predictors of LLL tendency.

\section{Discussion and conclusions}

In this study, it is intended to determine teachers' LLL tendency levels and to reveal the variables predicting LLL tendency levels. A relational model was designed for LLL tendency based on the reviews of the studies related to LLL. According to this MLRA model, within the context of this study, demographic and professional variables, and burnout are found to be significant predictors of LLL tendencies.

According to the findings of the study, it was determined that there was a negative relationship between age and LLL tendencies of teachers. The relative effect of demographic characteristics on LLL tendencies is in the order of age, educational status and gender. Age is the most effective predictive variable when the relative effect of demographic characteristics on LLL tendencies is examined. Accordingly, it was determined that the level of LLL tendency decreases when age increases. It is considered that the reason for this situation is that people take more responsibility in their working environments when they get older and therefore, they have less time to maintain their personal development. Scheuch, Shouping and Gaston (2009) emphasised that even though individuals have skills in the field, basic research and learning will diminish over time. Therefore, it can be said that the use of technological tools in education together with the changing society requires teachers to acquire new knowledge and skills in this regard. For this reason, the high LLL tendencies of teachers are important for the process of organising more effective educational environments.

On the other hand, it could be emphasised that in order to avoid a gap in terms of LLL tendencies depending on the age and years of service, the continuity of in-service training activities is important. In addition, in order for teachers to improve their knowledge and skills which they feel lacking or inadequate, cooperation may be started. For instance, it can be suggested that the content, process and scope of the meetings/seminars held at the beginning of the academic year can be reviewed and arranged to support the sustainability of LLL.

Nevertheless, an interesting result is that LLL tendencies of teachers with a bachelor's degree are higher than those with master's degree. Coskun and Demirel (2012) stated that as education level increases, individuals may develop frustration and this may affect their motivation toward LLL. Although it is not statistically significant, another result is that female teachers' LLL tendencies were higher than males. In relation to these results, Jenkins (2004) emphasised that because of women's deprivation of formal education, they perceive LLL as more important and more vital. At this point, it can be said that women's LLL tendencies being higher is an expected result. Ekinci (2008) stated that 
women's learning characteristics and learning preferences are different from those of men. Therefore, it can be stated that LLL tendencies differ according to gender.

Based on the results of MLRA, it could be concluded that professional variables have significant effects on teachers' LLL tendencies. The relative impact of demographic characteristics on LLL tendencies are in the order of years of job experience, total number of students that are being taught, type of school and socio-economic level of the school environment.

Another conclusion reached in this study is that years of job experience is the most significant predictor variable related to LLL tendency among professional variables. In the present study, years of job experience is the most important predictor of LLL tendency among professional variables. According to this conclusion, there is an inverse relationship between years of job experience and levels of teachers' LLL tendency. In the literature, it is stated that as the number of people professionals serve, as a part of their responsibilities, increases, their occupational job satisfaction and motivation will decrease (Cemaloglu \& Sahin, 2007; Torun, 1995).

Cemaloglu and Sahin (2007) state that teachers who teach in crowded classes can feel emotionally exhausted over time. Although even if they spend more time and energy for their students, they still could allocate less time for each individual student because of the class size or the number of students they have in their classes. Due to this situation, teachers feel that their efficiency level is low and thus, they are unsuccessful in their job. Therefore, it could be concluded that 'conditions of the school, type of school, the number of students, and the course load' variables can affect teacher's LLL tendency.

In accordance with the results of the study, there is an important negative correlation between LLL tendency and occupational burnout. Accordingly, it can be said that occupational burnout is a predictive variable of LLL tendency of teachers. According to Maslach et al. (2001), the individual and organisational consequences of burnout lead to poor work performance. Teachers' burnout could result as the loss of ideals about occupation, unwillingness and alienation from the profession. These could be observed in a number of different situations, including 'school type/level, restricted school culture, school infrastructure, deficiencies in school's resources, having problems with administration, organisational problems and demographic factors' (Durak \& Seferoglu, 2017). In addition, it is possible that teachers who feel burnout in technology-rich learning environments are likely to exhibit nonprofessional behaviours such as cyberloafing (Aghaz \& Sheikh, 2016). On this condition, it is expected that teachers' LLL tendencies will decrease.

It was also concluded that some of teachers' personal characteristics, professional variables and occupational burnout all together explained teachers' LLL tendencies. Based on this conclusion, it could be claimed that in-service professional development activities could be organised in a way that would help teachers to develop their LLL competencies and influence their tendencies towards LLL.

Literature about teachers' lifelong tendencies indicates that there are a number of different elements and dimensions that are related to LLL tendencies. These elements and dimensions which display teachers' LLL tendencies are presented in Figure 2.

LLL is about the continuity of learning which is very important, especially in today's world where there is a high level digital transformation. Thus, it could be advised that LLL applications are supported and these applications are integrated with information and communication technologies. Indeed, teachers' personal and professional self-development will positively affect their professional attitudes and accordingly their perceptions of LLL. This situation can be a solution for preventing the sense of burnout experienced by the teachers.

It could be concluded that the level of teachers' LLL tendencies decrease with age and years of job experience. Thus, it is important that teachers' technological competencies are continuously improved for preventing the decrease in their eagerness to learn. In addition, it is known that teachers who improve their information literacy skills will know how and where to access and effectively use the information they need. Therefore, it could be stated that teachers are provided with the information 
and skills they need in relation to information literacy competencies during their pre-service training, in other words, in teachers training institutions.

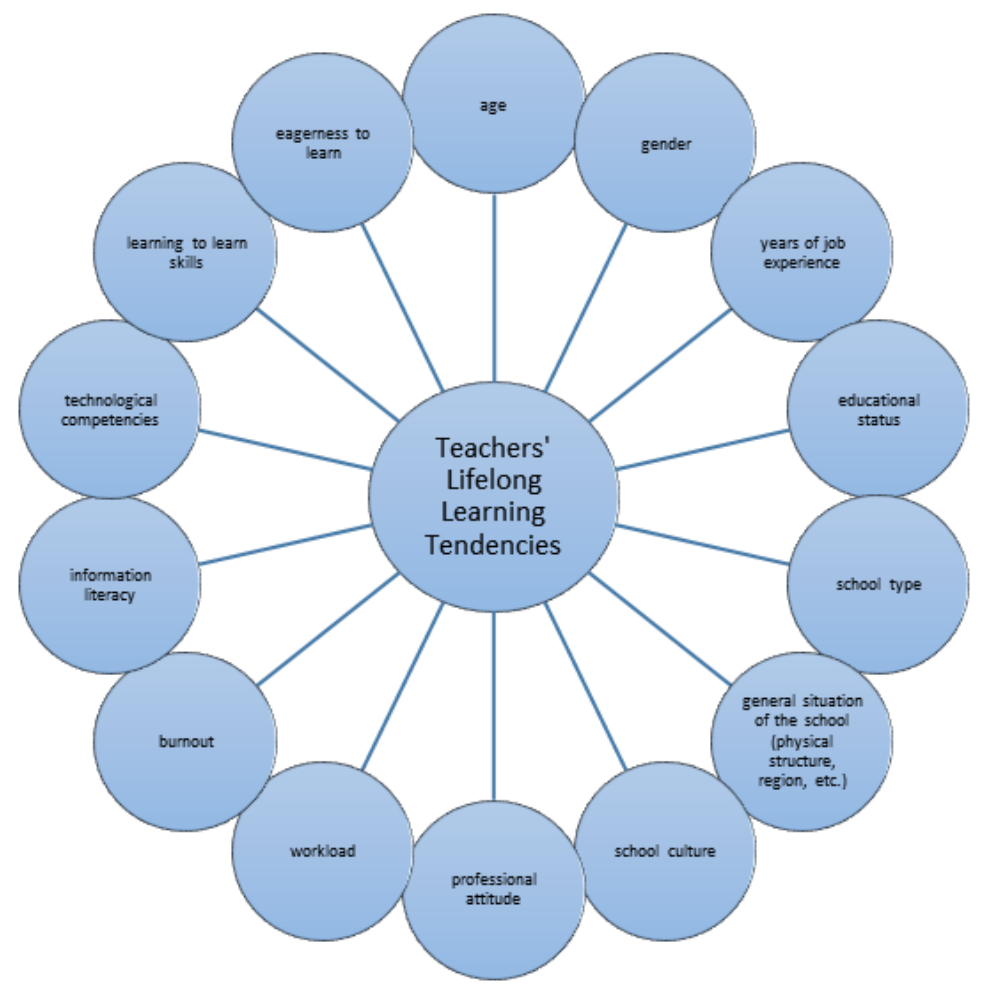

Figure 2. Teachers' LLL tendencies related elements

In conclusion, it could be argued that teachers who develop strong information literacy skills could be good role models for their students. These teachers will also experience less negative emotions and less professional burnout. Based on this statement, it could be suggested that teachers should be provided with in-service training activities which will help them to improve their information literacy skills. With competent and successful teachers, not only teachers themselves, but also school administrations, parents and students, in short, everybody will win.

\section{References}

Aghaz, A. \& Sheikh, A. (2016). Cyberloafing and job burnout: an investigation in the knowledge-intensive sector. Computers in Human Behavior, 62, 51-60. doi:10.1016/j.chb.2016.03.069

Akbas, O. \& Ozdemir, S. M. (2002). Avrupa Birliginde yasam boyu ogrenme. Milli Egitim Dergisi, 155(156), $112-126$.

Akkoyunlu, B. (2008). Bilgi okuryazarligi ve yasam boyu ogrenme (pp. 30-34). 8th International Educational Technology Conference (IETC), Eskisehir, Turkey, Anadolu Universitesi.

Beycioglu, K. \& Konan, N. (2008). Yasam boyu ogrenme ve Avrupa egitim politikalari. Elektronik Sosyal Bilimler Dergisi, 7(24) 369-382. Retrieved from https://dergipark.org.tr/tr/pub/esosder/issue/6138/82359

Brahmi, A. F. (2007). Medical students' perceptions of lifelong learning at Indiana University school of medicine (Unpublished doctoral dissertation). Indiana University, School of Library and Information Science, Bloomington, IN.

Budak, Y. (2009). Yasamboyu ogrenme ve ilkogretim programlarinin hedeflemesi gereken insan tipi. Gazi Universitesi Gazi Egitim Fakultesi Dergisi, 29(3), 693-708.

Cansever, B. A. (2009). Avrupa Birligi egitim politikalari ve Turkiye'nin bu politikalara uyum surecinin degerlendirilmesi. International Online Journal of Educational Sciences, 1(1), 222-232. 
Cemaloglu, N. \& Sahin, D. E. (2007). Ogretmenlerin mesleki tukenmislik duzeylerinin farkli degiskenlere gore incelenmesi. Kastamonu Egitim Dergisi, 15(2), 465-484.

Chapman, J., Toomey, R., Gaff, J., McGlip, J., Walsh, M., Warren, E. ... Williams, I. (2003) Lifelong learning and teacher education. Canberra, Australia: Australian Government Department of Education, Science and Training. Retrieved September, 10, 2018, from http://www.dest.gov.au/highered/eippubs.htm

Coskun, Y. D. \& Demirel, M. (2012). Universite ogrencilerinin yasam boyu ogrenme egilimleri. Hacettepe Universitesi Egitim Fakultesi Dergisi, 42, 108-120.

Damy, A. (2020). Interdisciplinary block of learning challenges. Contemporary Educational Researches Journal, 10(1), 21-27. doi:10.18844/cerj.v10i1.4611

Darkenwald, G. G. \& Merriam, S. B. (1982). Adult education: foundations of practice. New York, NY: Ty Crowell Co

Demirel, M. (2009). Ilkogretim programlarina yasam boyu ogrenme becerileri acisindan elestirel bir bakis. In Tam metin bildirileri kitabi (pp. 1-25). Canakkale, Turkey: Uluslararasi Egitim Arastirmalari Kongresi.

Diker-Coskun, Y. (2009). Universite ogrencilerinin yasam boyu ogrenme becerilerinin bazi degiskenler acisindan incelenmesi (Yayimlanmamis doktora tezi). Hacettepe Universitesi, Sosyal Bilimler Enstitusu, Ankara, Turkey.

Diker-Coskun, Y. \& Demirel, M. (2010). Lifelong learning tendency scale: The study of validity and reliability. Procedia-Social and Behavioral Sciences, 5, 2343-2350. doi:10.1016/j.sbspro.2010.07.461

Durak, H. \& Saritepeci, M. (2019). Occupational burnout and cyberloafing among teachers: analysis of personality traits, individual and occupational status variables as predictors. Social Science Journal, 56(1), 69-87.

Durak, H. Y. \& Seferoglu, S. S. (2017). Ogretmenlerde tukenmislik duygusunun cesitli degiskenler acisindan incelenmesi. Gazi Universitesi Gazi Egitim Fakultesi Dergisi, 37(2), 759-788.

Ekinci, N. (2008). Universite ogrencilerinin ogrenme yaklasimlarinin belirlenmesi ve ogretme-ogrenme sureci degiskenleri ile iliskileri (Yayimlanmamis doktora tezi). Hacettepe Universitesi, Sosyal Bilimler Enstitusu, Ankara, Turkey.

Erdamar, G., Demirkan, O., Saracoglu, G. \& Alpan, G. (2017). Lise ogretmenlerinin yasam boyu ogrenme egilimleri ve egitsel internet kullanma oz-yeterlik inanclari [The relationship between high school teachers' life-long learning tendencies and their educational Internet use self-efficacy beliefs]. Abant lzzet Baysal Universitesi Egitim Fakultesi Dergisi, 17(2), 636-657.

Ergin, C. (1992). Doktor ve hemsirelerde tukenmislik ve Maslach tukenmislik olceginin uyarlanmasi. VII. Ulusal Psikoloji Kongresi Bilimsel Calismalari, 22, 25.

European Commission. (2002). European Report on quality indicators of lifelong learning. Fifteen quality indicators. European Commission. Directorate-General for Education and Culture.

European Commission. (2019). Key competences for lifelong learning. Retrieved March 30, 2020, from https://op.europa.eu/en/publication-detail/-/publication/297a33c8-a1f3-11e9-9d0101aa75ed71a1/language-en

Evin Gencel, I. (2013). Ogretmen adaylarinin yasam boyu ogrenme yeterliklerine yonelik algilari. Egitim ve Bilim, 38(170), 237-254.

Field, A. (2009). Discovering statistics using SPSS. Thousand Oaks, CA: Sage publications.

Gorard, S. \& Selwyn, N. (2005). What makes a lifelong learner? Teachers College Record, 107(6), 1193-1216.

Gorard, S., Selwyn, N., Madden, L. \& Furlong, J. (2002). Technology and lifelong learning: are we cutting IT. In AllWales Education Research Conference: University of Wales Conference Centre, Newtown, UK: Gregynog, pp. 3-5.

Gunuc, S., Odabasi, H. F. \& Kuzu, A. (2012). Yasam boyu ogrenmeyi etkileyen faktorler. Gaziantep Universitesi Sosyal Bilimler Dergisi, 11(2), 309-325.

Izci, E. \& Koc, S. (2012). Ogretmen adaylarinin yasam boyu ogrenmeye iliskin goruslerinin degerlendirilmesi. Adiyaman Universitesi Sosyal Bilimler Enstitusu Dergisi, 5(9), 101-114.

Jenkins, A. (2004). Women, lifelong learning and employment. In Centre for the Economics of Education. U.K. London School of Economics and Political Science. Retrieved September 30, 2018, from http://cee.lse.ac.uk/ceedps/ceedp39.pdf 
Kara, D. \& Kurum, D. (2007). Sinif ogretmenligi adaylarinin "yasam boyu ogrenme" kavramina yukledikleri anlam. XVI. In E. Erginer (Ed.), Ulusal Egitim Bilimleri Kongresi (p. 1). Ankara, Turkey: Detay Yayincilik.

Karakus, C. (2013). Meslek yuksekokulu ogrencilerinin yasam boyu ogrenme yeterlikleri. Egitim ve Ogretim Arastirmalari Dergisi, 2(3), 26-35.

Kazu, I. Y. \& Erten, P. (2016). Ogretmenlerin yasam boyu ogrenme yeterlikleri. Ilkogretim Online, 15(3), 838-854.

Kilic, H. (2015). Ilkogretim brans ogretmenlerinin bireysel yenilikcilik duzeyleri ve hayat boyu ogrenme egilimleri (Denizli ili ornegi) (Yayimlanmamis yuksek lisans tezi). Pamukkale Universitesi Egitim Bilimleri Enstitusu, Denizli, Turkey.

Koksal, N. \& Cogmen, S. (2013). Pre-service teachers as lifelong learners: university facilities for promoting their professional development. Eurasian Journal of Educational Research, 53, 21-40.

Loads, D. (2007). Effective learning advisers' perceptions of their role in supporting lifelong learning. Teaching in

Higher Education, 12(2), 235-245. DOI: 10.1080/13562510701192016

Maslach, C. \& Goldberg, J. (1998). Prevention of burnout: new perspectives. Applied and Preventive Psychology, $7(1), 63-74$.

Maslach, C. \& Jackson, S. E. (1981). The measurement of burnout. Journal of Occupational Behavior, 2(2), 99-113. DOI: $10.1002 /$ job.4030020205

Maslach, C., Schaufeli, W. B. \& Leiter, M. P. (2001). Job burnout. Annual review of Psychology, 52(1), 397-422.

Maxted, P. (1999). Understanding barriers to learning: a guide to research and current thinking. London, UK: Campaign for Learning.

Oral, B. \& Yazar, T. (2015). Ogretmen adaylarinin yasam boyu ogrenmeye iliskin algilarinin cesitli degiskenlere gore incelenmesi. Elektronik Sosyal Bilimler Dergisi, 14(52), 1-11.

Sahin, Z. \& Durak, H. Y. (2018). Yetiskinlerin hayat boyu ogrenme becerilerinin gelistirilmesinde web 2.0 teknolojilerinin kullanimiyla ilgili arastirmalardaki guncel egilimlerle ilgili bir inceleme [An investigation on current trends in research on the use of Web 2.0 technologies in the development of lifelong learning skills of adult]. Journal of Research in Education, Science and Technology, 3(1), 23-34.

Saritepeci, M. \& Orak, C. (2019). Lifelong learning tendencies of prospective teachers: Investigation of selfdirected learning, thinking styles, ICT usage status and demographic variables as predictors. Bartin $\begin{array}{llll}\text { Universitesi Egitim } & \text { Fakultesi } & \text { 8(3), }\end{array}$ https://dergipark.org.tr/tr/pub/buefad/issue/49482/555478

Scheuch, K., Shouping, H. \& Gaston, G. J. (2009). The influences of faculty on undergraduate student participation in research and creative activities. Innovative Higher Education, 34(3), 173-183. https://doi.org/10.1007/s10755-009-9105-4

Sonmez, V. (2007). Ogretim ilke ve yontemleri. Ankara, Turkey: Ani Yayinlari.

Tabachnick, B. G. \& Fidell, L. S. (2007). Using multivariate statistics. Boston, MA: Allyn \& Bacon/London, UK: Pearson Education.

Tamer, M. G. (2014). Yasam boyu ogrenme icin ulusal yeterlilikler cercevesi: Avrupa ve Turkiye ornegi. International Journal of Curriculum and Instructional Studies, 3(5), 43-54.

Torun, A. (1995). Tukenmislik, aile yapisi ve sosyal destek iliskileri uzerine bir inceleme (Yayimlanmamis doktora tezi). Marmara Universitesi, Sosyal Bilimler Enstitusu, Istanbul, Turkey.

Troman, G. \& Woods, P. (2000). Careers under stress: teacher adaptations at a time of intensive reform. Journal of Educational Change, 1(3), 253-275.

Tunca, N., Sahin, S. A. \& Aydin, O. (2015). Ogretmen adaylarinin yasam boyu ogrenme egilimleri. Mersin Universitesi Egitim Fakultesi Dergisi, 11(2), 432-446. https://doi.org/10.17860/efd.92694

Uzunboylu, H. \& Hursen, C. (2011). Lifelong learning competence scale (LLLCS): the study of validity and reliability. Hacettepe University Journal of Education, 41, 449-460.

Vanichvatana, S. (2020). Who uses home as informal learning spaces: a Bangkok private university case study. World Journal on Educational Technology: Current Issues, 12(1), 37-47. doi:10.18844/wjet.v12i1.4416

Yaman, F. \& Yazar, T. (2015). Ogretmenlerin yasam boyu ogrenme egilimlerinin incelenmesi (Diyarbakir ili ornegi). Kastamonu Education Journal, 23(4), 1553-1566. 
Yildiz-Durak, H. \& Saritepeci, M. (2019). An examination on the reflections of cyber human values demonstrated by university students on lifelong learning trends. Journal of Computer and Education Research, 7(14), 418436. DOI: $\underline{10.18009 / \text { icer.601158 }}$ 